\title{
JURNALISME ONLINE PILKADA DKI 2017 (Pendekatan Analisis Isi Semantik Berita Online Pilkada DKI di DetikNews)
}

\author{
Angelika Rosma \\ Institut Ilmu Sosial dan Manajemen STIAMI \\ E-mail: be_shabrina@yahoo.com
}

\begin{abstract}
The Second Round of the DKI Regional Election on April 19, 2017 was an important event that attract the attention of many parties. Online news has become one of the sources of news that many have been waiting for because of its unique characteristics; interactive, immediacy, multimedia capability and non-linearity. One of the main sources of online news is Detiknews. This study aims to examine all the news on Detiknews on the election day in the 2017 DKI elections using semantic content analysis. The methodology used is descriptive qualitative. The results of the study resulted in 3 semantic content classifications from 46 researched articles. The conclusions obtained from all Detiknews online news about the Second Round of the DKI Pilkada on April 19, 2019 are good at describing all the important events that occurred that day.
\end{abstract}

Key words : Online Journalism, The DKI Regional Election, Semantic Content Analysis

\begin{abstract}
Abstrak
Babak Kedua Pemilihan Daerah DKI pada 19 April 2017 merupakan peristiwa penting yang menarik perhatian banyak pihak. Berita online telah menjadi salah satu sumber berita yang telah lama dinanti karena karakteristiknya yang unik; interaktif, kedekatan, kemampuan multimedia dan non-linearitas. Salah satu sumber utama berita online adalah Detiknews. Penelitian ini bertujuan untuk memeriksa semua berita tentang Detiknews pada hari pemilihan di Pemilu DKI 2017 menggunakan analisis konten semantik. Metodologi yang digunakan adalah deskriptif kualitatif. Hasil penelitian ini menghasilkan 3 klasifikasi konten semantik dari 46 artikel yang diteliti. Kesimpulan yang diperoleh dari semua berita online Detiknews tentang Putaran Kedua Pilkada DKI pada 19 April 2019 bagus untuk menggambarkan semua peristiwa penting yang terjadi hari itu.
\end{abstract}

Kata kunci: Jurnalisme Online, Pilkada DKI, Analisis Konten Semantik

\section{PENDAHULUAN}

Perhelatan Pilkada DKI di tahun 2017 bisa dikatakan merupakan salah satu pesta demokrasi yang paling banyak menyita perhatian seluruh masyarakat Indonesia, khususnya warga DKI Jakarta. Hal ini disebabkan pesta demokrasi tersebut memiliki masalah dan isu yang berbeda dibandingkan perhelatan pilkada di wilayah Indonesia lainnya.

Awalnya Komisi Pemilihan Umum

(KPU) Indonesia mengumumkan Pemilihan Kepala Daerah (Pilkada) serentak gelombang kedua tahun 2017, yaitu 15 Februari 2017. Pilkada di Indonesia akan diadakan serentak di tujuh provinsi, 18 kota dan 76 kabupaten.
Tanggal 15 Februari 2017 menjadi hari pilkada putaran pertama untuk DKI Jakarta. Namun, adanya kasus hukum penistaan agama tentang penyampaian Tafsir Surah Al-Maidah ayat 51 oleh Gubernur DKI saat itu, Basuki Tjahaja Purnama (Ahok), membuat perhelatan Pilkada DKI 2017 menjadi sangat menarik untuk diikuti perkembangannya dan dipelajari secara lebih dalam. Bahkan, gelombang protes umat Islam akan kasus ini kemudian dikenal dengan istilah "AlMaidah 511", melahirkan sebuah gerakan yang menamai dirinya Gerakan 212. Gerakan 212 adalah Gerakan aksi damai umat Islam di Jakarta yang diadakan tanggal 2 Desember 2016 untuk kasus penistiaan agama tersebut. 
Pilkada DKI 2017 mengalami 2 putaran, yaitu putaran pertama tanggal 15 Febuari 2017 yang dimenangkan (sementara) oleh pasangan pentahana dan putaran kedua tanggal 19 April 2017. Putaran kedua harus dilaksanakan karena pasangan pentahana hanya menang diangka 42,99\%, sedangkan UU Pilgub DKI mensyaratkan $51 \%$. Pernyataan ini bisa kita lihat saat Ketua KPUD Jakarta Sumarno mengumumkan secara resmi hasil pemilihan gubernur (Pilgub) DKI yang dilaksanakan 15 Februari 2017.

Sumarno menjelaskan setelah proses rekapitulais yang dilakukan dari level kelompok penyelenggara pemungutan suara (KPPS) hingga pleno yang dilakukan oleh KPUD Jakarta. Hasil dari proses rekapitulasi itu yakni, Pasangan Agus Harimurti Yudhoyono Sylviana Murni mendapatkan suara 937.950 dengan presentasi 17,02 \%, pasangan Basuki Tjahaja Purnama (Ahok)- Djarot Syaiful Hidayat memperoleh 2.364577 dengan presentase $42,99 \%$, sedangkan pasangan nomor urut 3 Anies Rasyid Baswedan-Sandiaga Salahudin Uno memperoleh 2.197.33 dengan presentase 39,95\%. "Tidak ada calon yang meraih suara 50\% plus 1," kata Sumarno, Sabtu (4/3/2017). Dari proses rekapitulasi itu, dikatakan Sumarno, bisa dipastikan belum ada satu pasanganpun yang meraih suara dengan presentasi melebihi 50\%. Sehingga jika mengacu pada UU pilgub DKI harus berlangsung dua putaran.

Selain pasangan petahana, kandidat lain yang merupakan saingan terkuat, yaitu pasangan mantan Menteri Pendidikan dan Kebudayaan Anies Baswedan dan Pengusaha Sandiaga Uno yang pada akhirnya terpilih sebagai pasangan Gurbenur dan Wakil Gubernur DKI Jakarta periode berikutnya; periode 2017-2022. Pasangan lain yang ikut meramaikan bursa bakal calon Gubernur dan Wakil Gubernur adalah pasangan mantan Perwira TNI Agus Harimurti Yhudoyono dan Sylviana Murni.

Putaran kedua Pilkada DKI Jakarta pada akhirnya dimenangkan oleh kandidat nomor urut 3 pasangan Anies Baswedan dan Sandiaga Uno yang dalam kampanyenya membawa

1

https://news.okezone.com/read/2017/03/04/338/1634341/i ni-hasil-pilgub-dki-putaran-pertama jargon "Maju Kotanya, Bahagia Warganya" dengan perolehan angka 3.240.987 juta suara atau $57,96 \%$, sedangkan pasangan kandidat 2 Basuki Tjahaja Purnama (Ahok) dan Djarrot Saiful Hidayat meraih 2.350.366 juta suara atau $42,04 \%$ suara. $^{2}$

Tingginya perhatian rakyat Indonesia dan warga DKI Jakarta di Pilkada DKI 2017, khususnya putaran kedua bisa dilihat dari semaraknya pemberitaan tentang perhelatan pesta demokrasi tersebut, termasuk di dalamnya berita online atau berita daring. Pemberitaan lainnya yang juga marak antara lain berita tentang banyaknya survey yang dilakukan beberapa lembaga survey dan beberapa putaran forum debat terbuka yang diadakan stasiun TV yang ditonton jutaan warga DKI, bahkan rakyat Indonesia di luar Provinsi DKI Jakarta.

Maraknya pemberitaan tentang Pilkada DKI Jakarta 2017 dalam berita-berita online terlihat dari berbagai situs online. Beberapa situs berita online yang aktif memberitakan diantaranya adalah www.republika.co.id, www.beritasatu.com, www.kompasiana.com., www. nasional.kompas.com, www.bbc.com, www.liputan6.com, dan www.detik.com

Tingginya animo masyarakat berpartisipasi dalam Pilkada DKI 2017 khususnya putaran 2 ini, bisa tercermin juga dalam pemberitaan online, dimana salah satu karakter dari pemberitaan adalah mencerminkan karakter masyarakat didalamnya, khususnya di waktu fenomena pemberitaan itu berlangsung.

Tujuan penelitian ini untuk melihat pemberitaan Detik.news dalam menyampaikan berbagai berita Pilkada DKI April 2017 ini. Dalam konteks inilah, analisis isi berita online Detik.news di tanggal 19 April 2017 menarik untuk dikaji dan dipelajari lebih jauh.

Beberapa kajian terdahulu yang terkait antara lain penelitian Vience Mutiara Rumata Puslitbang APTIKA-IKP, Kementerian Komunikasi dan Informatika tentang Objektivitas Berita Pada Media dalam Jaringan. (Analisis Isi Berita Pemilihan Gubernur DKI Jakarta pada Detiknews selama Masa

${ }^{2}$ https://megapolitan.kompas.com/read/2017/04/30/06030 941/ini.hasil.rekapitulasi.suara.putaran.kedua.pilkada.dki. jakarta 
Kampanye Periode I) dan penelitian Zartul Fadli, Magister Ilmu Komunikasi. Fakultas Ilmu Sosial dan Politik, Universitas Sumatera Utara tentang Metode Penelitian Kualitatif Analisis Teks.

\section{Jurnalisme Online}

Jurnalisme online saat ini menjadi salah satu sumber berita yang dinanti-nantikan oleh banyak pihak. Kemajuan bidang digital telah membawa kita pada speed baru dalam berbagai bidang, termasuk dalam bidang komunikasi, khususnya dalam hal ini bidang jurnalisme.

Jurnalisme online telah berkembang pesat sejak era internet pertama kali digunakan pada tahun 1969. Berkembangnya internet membawa kita pada sebuah istilah, yaitu Media Baru. Lister, 2003 menyebut beberapa karakter media baru, yaitu adanya unsur digitally, interactivity, hypertextual, networked, virtual, dan simulated.

Sementara Hadi (2010) mengatakan Jurnalistik adalah kegiatan mencari dan mengumpulkan informasi tentang kejadian yang ada di masyarakat, yang tidak dapat lepas dari kontruksi dari perspektif jurnalis yang bersangkutan yang kemudian menjadi berita. ${ }^{3}$

Lebih lanjut Hasfi (2009) mengatakan Jurnalisme Online adalah kegiatan jurnalistik yang melibatkan internet sebagai medium penyebaran informasi, dapat dilakukan oleh jurnalis profesional, atau jurnalis warga yang menulis melalui blog-blog individu.

Dalam perkembangannya, jurnalisme onlime memiliki beberapa karakter khusus. McQuail (2000) menyebutkan beberapa karakter jurnalisme online ${ }^{4}$, yaitu (1) Interaktivitas; Adanya karakter interaktivitas menjadi karakter pertama yang disebutkan McQuail. Para pembaca bisa ikut serta aktif memberikan respon atas berita yang disampaikan dan terciptalah komunikasi dua arah. Dalam perkembangan karakter interaktivitas inilah muncul hal baru lagi yang kemudian dikenal dengan istilah Citizen Journalism. Citizen Journalism menekankan

\footnotetext{
${ }^{3}$ Hadi, I.P., 2010. Perkembangan Teknologi Komunikasi dalam Era Jurnalistik Modern. Scriptura, 3(1), pp.69-84.

${ }^{4}$ Hasfi, N., 2009. Tantangan Jurnalis di Era Globalisasi Informasi. In Forum.
}

bahwa para pengguna tidak lagi hanya menerima informasi tetapi juga dapat ikut serta menyebarkan informasi. Di sisi lain, citizen journalism ini memunculkan polemik tentang rendahnya kualitas jurnalistik warga dan akurasinya; (2) Immediacy; berarti suatu berita dapat segera, cepat, update. Jurnalisme online menuntut suatu informasi disampaikan dengan cepat, dan selalu baru melebihi jurnalisme tradisional seperti koran atau majalah. Saat ada peristiwa yang baru saja terjadi, maka akan lebih cepat disampaikan melalui jurnalisme online dibandingkan jurnalisme tradisional. Teknologi internet memungkinkan hal itu terjadi; (3) Multimedia Capability; maksudnya informasi tidak hanya melalui tulisan, tetapi juga melalui foto, video, teks, dan audio. Karakter multimedia dalam pemberitaan jurnalisme online ini menjadi salah satu daya tarik terbesar para pembacanya, khususnya kalangan muda; dan (4) Non-liniearity; Karakter ini memungkinkan jurnalis bersikap fleksibel dalam menyampaikan berita, sedangkan para pembaca dapat memilih tema sesuai yang mereka inginkan.

\section{Analisis Isi}

Teknik sistematis untuk menganalisis suatu pesan atau suatu alat untuk mengobservasi dan mengnalisis isi perilaku kominikasi yang terbuka dari komunikator yang terpilih (Rahmat Kriyantono).

Analisis isi adalah teknik penelitian untuk membuat inferensi-inferensi yang dapat ditiru dan sahih data dengan memerhatikan konteksnya. Analisis isi berhubungan dengan komunikasi atau isi komunikasi. ${ }^{5}$ Beberapa bentuk klasifikasi dalam analisis isi $^{6}: 1$ ) Analisis Isi Pragmatis; Dimana klasifikasi dilakukan terhadap tanda menurut sebab akibatnya yang mungkin. Misalnya, berapa kali suatu kata tertentu diucapkan yang dapat mengakibatkan munculnya sikap suka tehadap suatu produk; 2) Analisis Isi Semantik; Dilakukan untuk mengklasifikasikan tanda

5 Bungin, Burhan. 2012. Penelitian Kualitatif; Komunikasi, Ekonomi, Kebijakan Publik, dan Ilmu Sosial lainnya.

6 Krippendorff, Klaus, 1991. Content Analysis: an introduction ot its Methodology. 
menurut maknanya. Terbagi dalam tiga jenis yaitu : a. Analisis penunjukan; Menggambarkan frekuensi seberapa sering objek tertentu dirujuk; b. Analisis Penyifatan; Menggambarkan frekuensi seberapa sering karakterisasi tertentu dirujuk; dan c. Analisis pernyataan; menggambarkan frekuensi seberapa sering objek tertentu dikarakteristikkan secara khusus ; dan terakhir 3) Analisis Sarana Tanda; Dilakukan untuk mengklasifikasikan isi pesan melalui sifat psikofisik dari tanda, misalnya berapa kali kata cantik muncul, kata seks muncul. Secara teknik Analisis isi mencakup upaya-upaya: klasifikasi lambang-lambang yang dipakai dalam komunikasi, menggunakan kriteria dalam klasifikasi dan menggunakan teknik analisis tertentu dalam membuat prediksi.

Analisis isi dapat mempertimbangkan "apa yang dikatakan seseorang (what)" tetapi tidak dapat menyelidiki "bagaimana seseorang mengatakan (how). Analisis isi didefinisikan oleh Atherton dan Klemack sebagai studi tentang arti komunikasi verbal. Bahan yang dipelajari dapat berupa bahan yang diucapkan atau bahan tertulis. Bahan yang dijadikan sumber data untuk analisis isi tidak hanya bahan pidato, tetapi juga dapat berupa buku harian, surat catatan kasus, dan semacamnya ${ }^{7}$.

Tujuan Analisis Isi ${ }^{8}$ ada beberapa, sebagaimana disampaikan Wimmer dan Dominic, yakni: (1) Menggambarkan isi komunikasi (Describing communiaction content); yaitu mengungkap kecenderungan yang ada pada isi komunikasi; (2) Menguji hipotesis karakteristik-karakteristik suatu pesan (Testing hypotheses of message characteristic). Sejumlah peneliti berusaha menghubungkan karakteristik tertentu dari komunikator (sumber) dengan karakteristik pesan yang dihasilkan; (3) Membandingkan isi media dengan "dunia nyata" (Comparing media content to the "real world'); (4) Melalui image suatu kelompok tertentu dan masyarakat (Assesing the image of particular groups in society); (5) Menciptakan titik awal terhadap studi efek media

\footnotetext{
${ }^{7}$ Soehartono, Irawan. 1999. Metode Penelitian Sosial. Hal 73

${ }^{8}$ Bulaeng, Andi. 2004. Metode Penelitian Komunikasi Kontemporer. Hal 171
}

(Establishing $s$ starting point for studies of media effects); dan (6) Bermanfaat bagi praktisi humas; Humas bisa mengukur opini publik dengan cara melihat bagaimana kecenderungan pemberitaan media terhadap perusahaan.

Dari 6 poin di atas, posisi peneliti berada pada di poin pertama. Tujuan peneliti dalam penelitian ini adalah menggambarkan isi berita yang ada di detiknews dan membaca kecenderungan yang ada dalam pemberitaan detiknews.

Dalam konsep analisis isi terdapat 2 jenis konsep yakni analisis isi kuantitatif dan analisis isi kualitatif. Perbedaan di antara kedua konsep penelitian ini adalah pada analisis isi kuantitatif lebih memfokuskan pada isi komunikasi yang tampak (tersurat/manifest/nyata). Sedangkan untuk menjelaskan hal -hal yang tersirat (latent), misalnya ideologi apa yang ada di balik suatu berita, maka dilakukan riset analisis isi kualitatif. Dalam perkembangan Ilmu Komunikasi, metode analisis isi kualitatif berkembang menjadi beberapa varian metode, antara lain: analisis framing, analisis wacana, dan semiotik. ${ }^{9}$

\section{METODE PENELITIAN}

Penelitian ini menggunakan pendekatan kualitatif. Penelitian kualitatif bertujuan memahami realitas sosial, yaitu melihat dunia dari apa adanya, bukan dunia yang seharusnya, maka seorang peneliti kualitatif harus memiliki sifat open minded. Karenanya, melakukan penelitian kualitatif dengan baik dan benar berarti telah memiliki jendela untuk memahami dunia psikologi dan realitas sosial. ${ }^{10}$

Dalam penelitian kualitatif, dikenal ada empat jenis sumber data, yaitu; subjek, informan, written document, dan unwritten documents. Menurut McCusker, K., \& Gunaydin, S. (2015), metode kualitatif digunakan untuk menjawab pertanyaan tentang "apa (what)", "bagaimana (how)", atau "mengapa (why)" atas suatu

\footnotetext{
9 Kriyantono. 2012. Public Relations \& Crisis Management: Pendekatan Critical Public Relations Etnografi Kritis \& Kualitatif. Jakarta: Kencana. Hal 51

10 . Koentjoro, Herdiansyah. 2014.
} 
Jurnal Komunikasi

ISSN 2580-8338

fenomena, sedangkan metode kuantitatif menjawab pertanyaan "berapa banyak (how many, how much)"11. Sementara itu, Tailor mengemukakan perbedaan penelitian dengan pendekatan metode kualitatif dan pendekatan metode kuantitatif, antara lain sebagai berikut ${ }^{12}$ :

${ }^{11}$ McCusker, K., \& Gunaydin, S. (2015). Research using qualitative, quantitative or mixed methods and choice based on the research.

12 Basri, H. 2014. Using qualitative research in accounting and management studies: not a new agenda. Journal of US-China Public Administration. 


\section{Tabel 1. Perbedaan Metode Kuantitatif dan Metode Kualitatif}

\begin{tabular}{|c|c|c|}
\hline No & Kuantitatif & Kualitatif \\
\hline 1 & $\begin{array}{l}\text { Sampel yang memadai, berdasarkan teori } \\
\text { "central limit theorem" (data dianggap } \\
\text { terdirstibusi normal). }\end{array}$ & $\begin{array}{l}\text { Sampel sedikit, tidak mewakili populasi dan } \\
\text { idiosinkratis, yaitu unik dan bersifat } \\
\text { individual. }\end{array}$ \\
\hline 2 & Kajian pustaka pada awal studi. & Kajian pustaka pada akhir studi. \\
\hline 3 & $\begin{array}{l}\text { Data dikumpulkan melalui instrumen yang } \\
\text { berdasarkan variabel yang telah } \\
\text { ditentukan. }\end{array}$ & $\begin{array}{l}\text { Menekankan pada pengorganisasian, } \\
\text { pengkoordinasian, dan mensintesa jumlah data } \\
\text { yang banyak. }\end{array}$ \\
\hline 4 & $\begin{array}{l}\text { Kontrol yang objektif atas bias replikasi } \\
\text { dan reliabel. }\end{array}$ & $\begin{array}{l}\text { Bersifat subjektif atas data individual dan } \\
\text { muatan nilai. }\end{array}$ \\
\hline 5 & Besifat deduktif. & Bersifat induktif \\
\hline 6 & Menguji teori & Mengembangkan teori \\
\hline 7 & $\begin{array}{l}\text { Mengambil kesimpulan berdasarkan } \\
\text { orientasi output data }\end{array}$ & $\begin{array}{l}\text { Mengembangkan nilai dan pengambilan } \\
\text { kesimpulan berdasarkan data, dengan } \\
\text { berorientasi pada proses }\end{array}$ \\
\hline 8 & $\begin{array}{l}\text { Penjelasan didapat dari interpretasi data- } \\
\text { data numerik }\end{array}$ & $\begin{array}{l}\text { Komplek dan pengalaman yang kaya (berisi), } \\
\text { terlepas dari data-data numerik }\end{array}$ \\
\hline 9 & dan validitas diketahui & tidak diketahui \\
\hline 10 & Perangkat pengukuran yang standar & gkat pengukuran ti \\
\hline 11 & $\begin{array}{l}\text { Intervensi, tidak ada keterlibatan } \\
\text { partisipan }\end{array}$ & Keterlibatan partisipan \\
\hline 12 & $\begin{array}{l}\text { Mengikuti metode ilmiah dengan } \\
\text { menggunakan } \mathrm{HO}+\mathrm{HA} \text { untuk menerima, } \\
\text { menolak, membuktikan, atau tidak } \\
\text { menerima hipotesis. }\end{array}$ & $\begin{array}{l}\text { Tidak mengikuti langkah-langkah metode } \\
\text { ilmiah, mencari makna dan substansi. }\end{array}$ \\
\hline 13 & Data numerik & $\begin{array}{l}\text { Data naratif - kata-kata untuk menggambarkan } \\
\text { kompleksitas }\end{array}$ \\
\hline 14 & $\begin{array}{l}\text { Menggunakan berbagai macam variasi } \\
\text { intrumen }\end{array}$ & $\begin{array}{l}\text { Pada prinsipnya menggunakan observasi dan } \\
\text { interview }\end{array}$ \\
\hline 15 & Dengan asumsi realitas yang stabil (statis) & Dengan asumsi realitas yang dinamis \\
\hline 16 & Berorientasi pada verifikasi & Berorientasi pada penemuan \\
\hline 17 & $\begin{array}{l}\text { Menganalisis realitas sosial melalui } \\
\text { variabel }\end{array}$ & $\begin{array}{l}\text { Melaksanakan observasi holistik dari total } \\
\text { kontek dalam kejadian-kejadian sosial }\end{array}$ \\
\hline 18 & $\begin{array}{l}\text { Menggunakan metode statistik untuk } \\
\text { menganalisis data }\end{array}$ & $\begin{array}{l}\text { Menggunakan analisis induksi untuk } \\
\text { menganalisis data }\end{array}$ \\
\hline 19 & $\begin{array}{l}\text { Mempelajari populasi atau sampel yang } \\
\text { merepresentasikan populasi }\end{array}$ & Studi kasus \\
\hline
\end{tabular}

Penelitian deskriptif kualitatif adalah penelitian yang menggambarkan atau melukiskan objek penelitian berdasarkan fakta-fakta yang tampak atau sebagaimana adanya. $^{13}$ Penelitian deskriptif kualitatif

\footnotetext{
${ }^{13}$ Hadari Nawawi, H. Murni Martini. 1996. Penelitian Terapan.
}

berusaha mendeskripsikan seluruh gejala atau keadaan yang ada, yaitu keadaan gejala menurut apa adanya pada saat penelitian dilakukan. $^{14}$ Desain analisis ini tidak dimaksudkan untuk menguji suatu hipotesis

\footnotetext{
${ }^{14}$ Mukhtar. 2013. Metode Penelitian Deskriftif Kualitatif. Hal 28
} 
tertentu atau menguji hubungan di antara variabel. Analisis isi semata untuk deskripsi, menggambarkan aspek -aspek dan karakteristik dari suatu pesan.

Sumber Data yang digunakan adalah semua berita onlinews Detik.news tentang Pilkada DKI 2017 dengan rentang masa waktu spesifik yaitu tanggal 19 April 2017. Sedangkan teknik pengumpulan data yang digunakan dalam penelitian ini adalah teknik pustaka (library research), simak, dan catat. Sebagai instrumen utamanya adalah peneliti sendiri, dalam hal ini peneliti membaca berita, mencermati, dan mencatat hal yang berkaitan dengan tujuan penelitian. Untuk analisis data, peneliti menggunakan analisis data kualitatif, yaitu dengan melakukan analisis secara langsung terhadap pemberitaan dalam berita online detiknews tentang Pilkada DKI 2017 melalui proses : (1) Data reduction, yaitu penulis memilih dan memilah-milah data yang akan dianalisis berupa kata, kalimat, atau ungkapan; (2) Data display, yaitu peneliti menampilkan data yang telah dipilih dan dipilah-pilah dan menganalisis jenisnya; (3) Verification, yaitu penulis menyimpulkan hasil analisis ${ }^{15}$

\section{HASIL DAN PEMBAHASAN Profil Detik.com}

Detik.com adalah sebuah portal web yang berisi berita dan artikel daring di Indonesia. Detik.com merupakan salah satu situs berita terpopuler di Indonesia. Berbeda dari situs-situs berita berbahasa Indonesia lainnya, Detik.com hanya mempunyai edisi daring dan menggantungkan pendapatan dari iklan. Meski begitu, Detik.com merupakan yang terdepan dalam hal berita-berita baru (breaking news). Sejak tanggal 3 Agustus 2011, detik.com menjadi bagian dari PT Trans Corporation, salah satu anak perusahaan CT Corp. ${ }^{16}$ (Wikipedia)

Ada dua kriteria utama pemilihan situs Detik.com dalam penelitian ini. Pertama, Detik.com merupakan media daring terlama dan terdepan dalam dunia jurnalistik online di

\footnotetext{
${ }^{15}$ Mukhtar. 2013. Hal 135

${ }^{16}$ https://id.wikipedia.org/wiki/DetikCom
}

Indonesia yang awalnya hanya bertemakan politik, ekonomi dan teknologi informasi. Hari kelahiran Detik.com ditetapkan pada tanggal 9 Juli 1998. Seiring perkembangan dan eksistensinya, Detik.com memperluas liputan beritanya dengan meliput berita hiburan dan olahraga. Kedua, Detik.com diperkirakan memiliki kunjungan perhari rata-rata $1,400,354$ pengunjung dan jumlah halaman yang dikunjungi 3,400,385 kali halaman dengan pendapatan Google Adsensenya mencapai $\$ 10.000$ atau kurang lebih Rp130 juta per hari. ${ }^{17}$

Kedua kriteria diatas yang menjadi pertimbangan dipilihnya Detik.com dalam penelitian ini. Selain itu, ada kriteria ketiga yang tidak dapat diabaikan, yakni karena Detik.com lama berada dalam posisi pertama sebagai situs online yang paling populer dan terbanyak dikunjungi. Namun, karena keterbatasan waktu dan tenaga, peneliti membatasi pembahasan berita online Pilkada DKI 2017 hanya pada situs detik.com selama tanggal 19 April 2017.

\section{Hasil Penelitian}

Berdasarkan teknik analisis data, ada 46 berita online detiknews tentang Pilkada DKI pada tanggal 19 April 2017 yang diteliti. Adapun jumlah total berita pilkada DKI 2017 di Detik.news yang peneliti baca berjumlah 50 berita. Semua berita yang terkumpul diverifikasi dan dimasukkan ke dalam 3 klasifikasi analisis isi semantik. Untuk memudahkan pembahasan penelitian, berita online Detiknews yang telah dikumpulkan bisa dilihat dalam Tabel 2 berikut ini:

\footnotetext{
17 https://chyrun.com/peringkat-5-media-onlinepopuler-di-indonesia-beserta-pendapatanya/
} 
Angelika Rosma, Jurnalisme Online Pilkada DKI 2017 ...

Tabel 2. Analisis Isi Semantik

\begin{tabular}{|c|c|c|c|c|}
\hline $\begin{array}{c}\text { Analisis Isi } \\
\text { Semantik }\end{array}$ & Judul & Tanggal & Jurnalis & $\begin{array}{l}\text { Kata } \\
\text { Kunci }\end{array}$ \\
\hline \multirow{10}{*}{$\begin{array}{l}\text { (Menggambarkan } \\
\text { frekuensi } \\
\text { seberapa sering } \\
\text { terdapat berita } \\
\text { tentang Pilkada } \\
\text { DKI pada Rabu } \\
19 \text { April 2017) }\end{array}$} & $\begin{array}{l}\text { 1.Live Report: } \\
\text { Pilkada DKI } \\
\text { Jakarta Putaran } \\
\text { Kedua }\end{array}$ & $\begin{array}{l}\text { Rabu 19 April } \\
\text { 2017, 05:59 } \\
\text { WIB }\end{array}$ & Andhika Prasetia & $\begin{array}{l}\text { Live Report, } \\
\text { Pengawasan }\end{array}$ \\
\hline & $\begin{array}{l}\text { 2. Selamat Datang } \\
\text { di Live Report: } \\
\text { Penentuan Kursi } \\
\text { DKI }\end{array}$ & $\begin{array}{l}\text { Rabu 19 April } \\
2017,06: 16 \\
\text { WIB }\end{array}$ & $\begin{array}{l}\text { Andhika Prasetia } \\
\text { dan Tim }\end{array}$ & $\begin{array}{l}\text { Live Report, } \\
\text { Pengawasan }\end{array}$ \\
\hline & $\begin{array}{l}\text { 3. Begini Suasana } \\
\text { TPS } 54 \text { Tempat } \\
\text { Ahok dan Keluarga } \\
\text { Mencoblos }\end{array}$ & $\begin{array}{l}\text { Rabu } 19 \text { April } \\
\text { 2017, 06:46 } \\
\text { WIB }\end{array}$ & $\begin{array}{l}\text { Andhika Prasetia } \\
\text { dan Tim }\end{array}$ & $\begin{array}{l}\text { Live Report, } \\
\text { Pengawasan }\end{array}$ \\
\hline & $\begin{array}{l}\text { 4. Pilgub DKI } \\
\text { Jakarta Putaran 2, } \\
\text { Ayo Mencoblos } \\
\text { Mulai Pukul } 07.00\end{array}$ & $\begin{array}{l}\text { Rabu 19 April } \\
\text { 2017, 07:07 } \\
\text { WIB }\end{array}$ & $\begin{array}{l}\text { Andhika Prasetia } \\
\text { dan Tim }\end{array}$ & $\begin{array}{l}\text { Live Report, } \\
\text { Pengawasan }\end{array}$ \\
\hline & $\begin{array}{l}\text { 5. Final Pilgub DKI } \\
\text { Jakarta dalam } \\
\text { Angka }\end{array}$ & $\begin{array}{l}\text { Rabu 19 April } \\
2017,07: 10 \\
\text { WIB }\end{array}$ & $\begin{array}{l}\text { Andhika Prasetia } \\
\text { dan Tim }\end{array}$ & $\begin{array}{l}\text { Live Report, } \\
\text { Pengawasan }\end{array}$ \\
\hline & $\begin{array}{l}\text { 6. Kenakan Kemeja } \\
\text { Abu-abu, Ahok Tiba } \\
\text { di TPS } 54 \text { Pluit }\end{array}$ & $\begin{array}{l}\text { Rabu 19 April } \\
2017,07: 52 \\
\text { WIB }\end{array}$ & $\begin{array}{l}\text { Andhika Prasetia } \\
\text { dan Tim }\end{array}$ & $\begin{array}{l}\text { Live Report, } \\
\text { Pengawasan }\end{array}$ \\
\hline & $\begin{array}{l}\text { 7. TPS Habib Rizieq } \\
\text { Dipindah }\end{array}$ & $\begin{array}{l}\text { Rabu 19 April } \\
\text { 2017, 08:13 } \\
\text { WIB }\end{array}$ & $\begin{array}{l}\text { Andhika Prasetia } \\
\text { dan Tim }\end{array}$ & $\begin{array}{l}\text { Live Report, } \\
\text { Pengawasan }\end{array}$ \\
\hline & $\begin{array}{l}\text { 8. Begini Suasana } \\
\text { TPS IV Tempat } \\
\text { Jokowi Nyoblos }\end{array}$ & $\begin{array}{l}\text { Rabu 19 April } \\
\text { 2017, 08:17 } \\
\text { WIB }\end{array}$ & $\begin{array}{l}\text { Andhika Prasetia } \\
\text { dan Tim }\end{array}$ & $\begin{array}{l}\text { Live Report, } \\
\text { Pengawasan }\end{array}$ \\
\hline & $\begin{array}{l}\text { 9. Agus Yudhoyono } \\
\text { Mencoblos di TPS } \\
\text { O6 Cibeber Jaksel }\end{array}$ & $\begin{array}{l}\text { Rabu 19 April } \\
\text { 2017, 08:26 } \\
\text { WIB }\end{array}$ & $\begin{array}{l}\text { Andhika Prasetia } \\
\text { dan Tim }\end{array}$ & $\begin{array}{l}\text { Live Report, } \\
\text { Pengawasan }\end{array}$ \\
\hline & $\begin{array}{l}\text { 10. Bersama Istri, } \\
\text { Djarot Mencoblos } \\
\text { di TPS } 08\end{array}$ & $\begin{array}{l}\text { Rabu 19 April } \\
\text { 2017, 08:31 } \\
\text { WIB }\end{array}$ & $\begin{array}{l}\text { Andhika Prasetia } \\
\text { dan Tim }\end{array}$ & $\begin{array}{l}\text { Live Report, } \\
\text { Pengawasan }\end{array}$ \\
\hline
\end{tabular}




\begin{tabular}{l|lll}
$\begin{array}{l}\text { 11. Kapolri, } \\
\text { Kapolda dan }\end{array}$ & $\begin{array}{l}\text { Rabu 19 April } \\
\text { 2017, 08:50 }\end{array}$ & $\begin{array}{l}\text { Andhika Prasetia } \\
\text { dan Tim }\end{array}$ & $\begin{array}{l}\text { Live Report, } \\
\text { Pengawasan }\end{array}$ \\
$\begin{array}{l}\text { Pencoblosan di TPS } \\
\text { WIB }\end{array}$ & & & \\
$\begin{array}{l}\text { 12. Polisi-TNI } \\
\text { Kenakan Pin 'Aman } \\
\text { Ada Kami' di Pilgub }\end{array}$ & $\begin{array}{l}\text { Rabu 19 April } \\
\text { 2017, 10:09 }\end{array}$ & $\begin{array}{l}\text { Andhika Prasetia } \\
\text { dan Tim }\end{array}$ & $\begin{array}{l}\text { Live Report, } \\
\text { Pengawasan }\end{array}$ \\
& & &
\end{tabular}

\section{Pantau Quick Count Pilgub DKI di detikcom Mulai Pukul 13.00 WIB}

\begin{tabular}{|c|c|c|c|}
\hline $\begin{array}{l}\text { 14.Anies Tiba di } \\
\text { TPS } 28 \text { Bersama } \\
\text { Keluarga }\end{array}$ & $\begin{array}{l}\text { Rabu 19 April } \\
2017,10: 25 \\
\text { WIB }\end{array}$ & $\begin{array}{l}\text { Andhika Prasetia } \\
\text { dan Tim }\end{array}$ & $\begin{array}{l}\text { Live Report, } \\
\text { Pengawasan }\end{array}$ \\
\hline $\begin{array}{l}\text { 15.Jokowi dan } \\
\text { Iriana Mencoblos di } \\
\text { TPS } 04 \text { Gambir }\end{array}$ & $\begin{array}{l}\text { Rabu 19 April } \\
2017,10: 49 \\
\text { WIB }\end{array}$ & $\begin{array}{l}\text { Andhika Prasetia } \\
\text { dan Tim }\end{array}$ & $\begin{array}{l}\text { Live Report, } \\
\text { Pengawasan }\end{array}$ \\
\hline $\begin{array}{l}\text { 16. JK Mencoblos } \\
\text { dan Cicipi Bir } \\
\text { Pletok di TPS } 03\end{array}$ & $\begin{array}{l}\text { Rabu 19 April } \\
2017,11: 06 \\
\text { WIB }\end{array}$ & $\begin{array}{l}\text { Andhika Prasetia } \\
\text { dan Tim }\end{array}$ & $\begin{array}{l}\text { Live Report, } \\
\text { Pengawasan }\end{array}$ \\
\hline $\begin{array}{l}\text { 17. Salam OK OCE } \\
\text { dari TPS Rutan } \\
\text { KPK }\end{array}$ & $\begin{array}{l}\text { Rabu 19 April } \\
2017,11: 42 \\
\text { WIB }\end{array}$ & $\begin{array}{l}\text { Andhika Prasetia } \\
\text { dan Tim }\end{array}$ & $\begin{array}{l}\text { Live Report, } \\
\text { Pengawasan }\end{array}$ \\
\hline $\begin{array}{l}\text { 18.Agus Yudhoyono } \\
\text { dan Annisa Pohan } \\
\text { Mencoblos di TPS } \\
\text { O6 }\end{array}$ & $\begin{array}{l}\text { Rabu 19 April } \\
2017,11: 52 \\
\text { WIB }\end{array}$ & $\begin{array}{l}\text { Andhika Prasetia } \\
\text { dan Tim }\end{array}$ & $\begin{array}{l}\text { Live Report, } \\
\text { Pengawasan }\end{array}$ \\
\hline $\begin{array}{l}\text { 19. Melihat Aksi } \\
\text { Tamasya Al Maidah } \\
\text { di } 2 \text { TPS di Benhil }\end{array}$ & $\begin{array}{l}\text { Rabu } 19 \text { April } \\
2017,12: 48 \\
\text { WIB }\end{array}$ & $\begin{array}{l}\text { Andhika Prasetia } \\
\text { dan Tim }\end{array}$ & $\begin{array}{l}\text { Live Report, } \\
\text { Pengawasan }\end{array}$ \\
\hline $\begin{array}{l}\text { 20. TPS Ditutup } \\
\text { Pukul } 13.00 \text { WIB }\end{array}$ & $\begin{array}{l}\text { Rabu 19 April } \\
2017,13: 05 \\
\text { WIB }\end{array}$ & $\begin{array}{l}\text { Andhika Prasetia } \\
\text { dan Tim }\end{array}$ & $\begin{array}{l}\text { Live Report, } \\
\text { Pengawasan }\end{array}$ \\
\hline $\begin{array}{l}\text { 21. Penghitungan } \\
\text { Suara di Berbagai } \\
\text { TPS Dimulai }\end{array}$ & $\begin{array}{l}\text { Rabu 19 April } \\
\text { 2017, 13:17 } \\
\text { WIB }\end{array}$ & $\begin{array}{l}\text { Andhika Prasetia } \\
\text { dan Tim }\end{array}$ & $\begin{array}{l}\text { Live Report, } \\
\text { Pengawasan }\end{array}$ \\
\hline
\end{tabular}


Angelika Rosma, Jurnalisme Online Pilkada DKI 2017 ...

\begin{tabular}{|c|c|c|c|c|}
\hline & $\begin{array}{l}\text { 22. Hasil Quick } \\
\text { Count Pilgub DKI } \\
\text { Putaran Kedua } \\
\text { Pukul } 14.14 \text { WIB }\end{array}$ & $\begin{array}{l}\text { Rabu 19 April } \\
2017,14: 15 \\
\text { WIB }\end{array}$ & $\begin{array}{l}\text { Andhika Prasetia } \\
\text { dan Tim }\end{array}$ & $\begin{array}{l}\text { Live Report, } \\
\text { Pengawasan }\end{array}$ \\
\hline & $\begin{array}{l}\text { 23. Hasil Quick } \\
\text { Count Pilgub DKI } \\
\text { Putaran Kedua } \\
\text { Pukul } 15.00 \text { WIB }\end{array}$ & $\begin{array}{l}\text { Rabu 19 April } \\
2017,15: 08 \\
\text { WIB }\end{array}$ & $\begin{array}{l}\text { Andhika Prasetia } \\
\text { dan Tim }\end{array}$ & $\begin{array}{l}\text { Live Report, } \\
\text { Pengawasan }\end{array}$ \\
\hline & $\begin{array}{l}\text { 24. Habib Rizieq ke } \\
\text { Istiqlal, Disambut } \\
\text { Takbir Peserta } \\
\text { Tamasya Al Maidah }\end{array}$ & $\begin{array}{l}\text { Rabu 19 April } \\
2017,17: 44 \\
\text { WIB }\end{array}$ & $\begin{array}{l}\text { Andhika Prasetia } \\
\text { dan Tim }\end{array}$ & $\begin{array}{l}\text { Live Report, } \\
\text { Pengawasan }\end{array}$ \\
\hline & $\begin{array}{l}\text { 25. Quick Count } \\
\text { Pilgub DKI } \\
\text { Quick Count Final } \\
\text { Median: Ahok } \\
\text { 41,99\%, Anies } \\
58,01 \%\end{array}$ & $\begin{array}{l}\text { Rabu 19 April } \\
2017,18: 26 \\
\text { WIB }\end{array}$ & Erwin Dariyanto & Kemenangan \\
\hline $\begin{array}{l}\text { 2. Analisis } \\
\text { Penyifatan }\end{array}$ & $\begin{array}{l}\text { 1. Anies-Sandi Salat } \\
\text { Subuh di Masjid } \\
\text { Dekat Rumah } \\
\text { Masing-masing }\end{array}$ & $\begin{array}{l}\text { Rabu 19 April } \\
2017,06: 27 \\
\text { WIB }\end{array}$ & $\begin{array}{l}\text { Andhika Prasetia } \\
\text { dan Tim }\end{array}$ & $\begin{array}{l}\text { Shalat } \\
\text { Subuh, } \\
\text { Mesjid }\end{array}$ \\
\hline $\begin{array}{l}\text { frekuensi } \\
\text { seberapa sering } \\
\text { karakterisasi } \\
\text { Pilkada DKI dan }\end{array}$ & $\begin{array}{l}\text { 2. Usai Salat Subuh, } \\
\text { Anies Tunggangi } \\
\text { Vesp a Beli Jajanan } \\
\text { Pasar }\end{array}$ & $\begin{array}{l}\text { Rabu 19 April } \\
2017,07: 18 \\
\text { WIB }\end{array}$ & $\begin{array}{l}\text { Andhika Prasetia } \\
\text { dan Tim }\end{array}$ & $\begin{array}{l}\text { Vespa, } \\
\text { Jajanan Pasar }\end{array}$ \\
\hline $\begin{array}{l}\text { Para Kandidatnya } \\
2017 \text { ditampilkan } \\
\text { pada } 19 \text { April } \\
\text { 2017) }\end{array}$ & $\begin{array}{l}\text { 3. Tenda Biru } \\
\text { Tempat Djarot dan } \\
\text { Keluarga } \\
\text { Mencoblos }\end{array}$ & $\begin{array}{l}\text { Rabu 19 April } \\
2017,07: 21 \\
\text { WIB }\end{array}$ & $\begin{array}{l}\text { Andhika Prasetia } \\
\text { dan Tim }\end{array}$ & $\begin{array}{l}\text { Tempat } \\
\text { Djarot } \\
\text { Mencoblos }\end{array}$ \\
\hline & $\begin{array}{l}\text { 4. Sandiaga Jogging } \\
\text { Cek } 3 \text { TPS Dekat } \\
\text { Rumahnya }\end{array}$ & $\begin{array}{l}\text { Rabu 19 April } \\
2017,07: 36 \\
\text { WIB }\end{array}$ & $\begin{array}{l}\text { Andhika Prasetia } \\
\text { dan Tim }\end{array}$ & $\begin{array}{l}\text { Jogging, Cek } \\
3 \text { TPS }\end{array}$ \\
\hline & $\begin{array}{l}\text { 5. Nyoblos di TPS } \\
\text { O1, Sandiaga Pamer } \\
\text { Salam } 3 \text { Jari }\end{array}$ & $\begin{array}{l}\text { Rabu 19 April } \\
\text { 2017, 08:54 } \\
\text { WIB }\end{array}$ & $\begin{array}{l}\text { Andhika Prasetia } \\
\text { dan Tim }\end{array}$ & Salam 3 Jari \\
\hline & $\begin{array}{l}\text { 6. Coblos di } \\
\text { Petamburan, Habib } \\
\text { Rizieq Salam } 3 \text { Jari }\end{array}$ & $\begin{array}{l}\text { Rabu 19 April } \\
2017,08: 47 \\
\text { WIB }\end{array}$ & $\begin{array}{l}\text { Andhika Prasetia } \\
\text { dan Tim }\end{array}$ & Salam 3 Jari \\
\hline
\end{tabular}




$\begin{array}{llll}\text { 7. Usai Mencoblos, } & \text { Rabu 19 April } & \text { Andhika Prasetia } & \text { Bergegas, } \\ \text { Ahok Bergegas ke } & \text { 2017, 09:06 } & \text { dan Tim } & \text { Kediaman } \\ \text { Kediaman } & \text { WIB } & & \text { Megawati } \\ \text { Megawati } & & & \end{array}$

\begin{tabular}{|c|c|c|c|}
\hline $\begin{array}{l}\text { 8. Pesan Jokowi } \\
\text { dan JK untuk Pilgub } \\
\text { DKI Putaran Kedua }\end{array}$ & $\begin{array}{l}\text { Rabu 19 April } \\
\text { 2017, 12:05 } \\
\text { WIB }\end{array}$ & $\begin{array}{l}\text { Andhika Prasetia } \\
\text { dan Tim }\end{array}$ & $\begin{array}{l}\text { Pesan Jokowi } \\
\text { dan JK }\end{array}$ \\
\hline $\begin{array}{l}\text { 9. Presiden PKS: } \\
\text { Anies-Sandi Unggul } \\
\text { di Exit Poll Kami }\end{array}$ & $\begin{array}{l}\text { Rabu 19 April } \\
2017,13: 50 \\
\text { WIB }\end{array}$ & $\begin{array}{l}\text { Andhika Prasetia } \\
\text { dan Tim }\end{array}$ & $\begin{array}{l}\text { Pesan Jokowi } \\
\text { dan JK }\end{array}$ \\
\hline $\begin{array}{l}\text { 10. Ahok Menang } \\
\text { Telak di TPS } \\
\text { Tempat Mencoblos }\end{array}$ & $\begin{array}{l}\text { Rabu 19 April } \\
2017,14: 43 \\
\text { WIB }\end{array}$ & $\begin{array}{l}\text { Andhika Prasetia } \\
\text { dan Tim }\end{array}$ & $\begin{array}{l}\text { Unggul di } \\
\text { TPS Djarot }\end{array}$ \\
\hline $\begin{array}{l}\text { 11. Anies Berjaya di } \\
\text { TPS Tempat } \\
\text { Mencoblos }\end{array}$ & $\begin{array}{l}\text { Rabu 19 April } \\
2017,14: 55 \\
\text { WIB }\end{array}$ & $\begin{array}{l}\text { Andhika Prasetia } \\
\text { dan Tim }\end{array}$ & $\begin{array}{l}\text { Unggul di } \\
\text { TPS }\end{array}$ \\
\hline $\begin{array}{l}\text { 12. Anies Gelar } \\
\text { Pertemuan Tertutup } \\
\text { di Rumah Prabowo }\end{array}$ & $\begin{array}{l}\text { Rabu } 19 \text { April } \\
\text { 2017, 15:18 } \\
\text { WIB }\end{array}$ & $\begin{array}{l}\text { Andhika Prasetia } \\
\text { dan Tim }\end{array}$ & $\begin{array}{l}\text { Pertemuan } \\
\text { tertutup, } \\
\text { Rumah } \\
\text { Prabowo }\end{array}$ \\
\hline $\begin{array}{l}\text { 13. Sandiaga Kalah } \\
\text { di TPS Tempat } \\
\text { Mencoblos }\end{array}$ & $\begin{array}{l}\text { Rabu 19 April } \\
2017,15: 35 \\
\text { WIB }\end{array}$ & $\begin{array}{l}\text { Andhika Prasetia } \\
\text { dan Tim }\end{array}$ & $\begin{array}{l}\text { Sandiaga } \\
\text { Kalah }\end{array}$ \\
\hline $\begin{array}{l}\text { 14.Djarot Merapat } \\
\text { ke Pullman }\end{array}$ & $\begin{array}{l}\text { Rabu 19 April } \\
2017,16: 20 \\
\text { WIB }\end{array}$ & $\begin{array}{l}\text { Andhika Prasetia } \\
\text { dan Tim }\end{array}$ & $\begin{array}{l}\text { Merapat } \\
\text { (Mendatangi) } \\
\text {, Pullman } \\
\text { (Hotel } \\
\text { Pullman) }\end{array}$ \\
\hline $\begin{array}{l}\text { 15.Anies: Kami } \\
\text { Mengabdi pada } \\
\text { Seluruh Warga } \\
\text { Jakarta }\end{array}$ & $\begin{array}{l}\text { Rabu 19 April } \\
\text { 2017, 18:05 } \\
\text { WIB }\end{array}$ & $\begin{array}{l}\text { Noval Dhwinuari } \\
\text { Antony }\end{array}$ & Pengabdian \\
\hline $\begin{array}{l}\text { 16. Habib Rizieq: } \\
\text { Calon Gubernur } \\
\text { Pemenang akan } \\
\text { Temani Kita di } \\
\text { Istiqlal }\end{array}$ & $\begin{array}{l}\text { Rabu 19 April } \\
2017,18: 34 \\
\text { WIB }\end{array}$ & $\begin{array}{l}\text { Edward Febriyatri } \\
\text { Kusuma }\end{array}$ & $\begin{array}{l}\text { Live Report, } \\
\text { Pengawasan }\end{array}$ \\
\hline $\begin{array}{l}\text { 17. Kalah dari } \\
\text { Anies, Ahok Tak }\end{array}$ & $\begin{array}{l}\text { Rabu 19 April } \\
2017,20: 30 \\
\text { WIB }\end{array}$ & Bisma Alief Laksana & $\begin{array}{l}\text { Menerima } \\
\text { Kekalahan }\end{array}$ \\
\hline
\end{tabular}


akan Gugat Hasil

Pilgub DKI 2017

\begin{tabular}{|c|c|c|c|c|}
\hline $\begin{array}{l}\text { 3.Analisis } \\
\text { Pernyataan } \\
\text { (Menggambarkan } \\
\text { frekuensi }\end{array}$ & $\begin{array}{l}\text { 1. Pilgub DKI } \\
\text { Putaran Kedua } \\
\text { Ahok-Djarot } \\
\text { Ucapkan Selamat } \\
\text { Atas Kemenangan } \\
\text { Anies-Sandi }\end{array}$ & $\begin{array}{l}\text { Rabu 19 April } \\
2017,17: 30 \\
\text { WIB }\end{array}$ & $\begin{array}{l}\text { Nathania Riris } \\
\text { Michico }\end{array}$ & Kemenangan \\
\hline $\begin{array}{l}\text { seberapa sering } \\
\text { objek tertentu } \\
\text { dikarakteristikka } \\
\text { n secara khusus) }\end{array}$ & $\begin{array}{l}\text { 2. Anies-Sandi } \\
\text { Menang Versi } \\
\text { Quick Count }\end{array}$ & $\begin{array}{l}\text { Rabu 19 April } \\
2017,17: 36 \\
\text { WIB }\end{array}$ & Erwin Dariyanto & Kemenangan \\
\hline $\begin{array}{l}\text { Dalam hal ini } \\
\text { adalah saat Para } \\
\text { Kandidat Peserta } \\
\text { Pilkada DKI atau } \\
\text { Tokoh Politik } \\
\text { lainnya yang }\end{array}$ & $\begin{array}{l}\text { 3. Ical Hadir di } \\
\text { Jumpa Pers Anies- } \\
\text { Sandi, Golkar: Akan } \\
\text { Kita Bicarakan }\end{array}$ & $\begin{array}{l}\text { Rabu 19 April } \\
2017,18: 02 \\
\text { WIB }\end{array}$ & Bisma Alief Laksana & $\begin{array}{l}\text { Dukungan } \\
\text { politik }\end{array}$ \\
\hline $\begin{array}{l}\text { terkait dalam } \\
\text { Pilkada DKI } \\
2017\end{array}$ & $\begin{array}{l}\text { 4. Pilgub DKI } \\
\text { Putaran Kedua } \\
\text { Aman dan Lancar. } \\
\text { Terima Kasih }\end{array}$ & $\begin{array}{l}\text { Rabu 19 April } \\
2017,18: 24 \\
\text { WIB }\end{array}$ & $\begin{array}{l}\text { Andhika Prasetia } \\
\text { dan Tim }\end{array}$ & $\begin{array}{l}\text { Live Report, } \\
\text { Pengawasan }\end{array}$ \\
\hline
\end{tabular}

Tabel 2. Analisis Isi Semantik Berita Online Detiknews tentang Pilkada DKI 2017, tanggal 19 April 2017

\section{Pembahasan}

Dalam Tabel 2, Peneliti sudah mengklasifikasikan berita pilkada DKI 2017 dalam 3 Klasifikasi Analisa Isi Semantik. Peneliti akan menginterpretasi setiap kelompok klasifikasi tersebut.

\section{Klasifikasi Analisis Isi Semantik Penunjukkan}

Dalam klasifikasi analisa isi semantik penunjukan ini total terdapat 25 berita yang ditampilkan. Klasifikasi semantik penunjukkan ini memuat total berita terbanyak dari 3 klasifikasi yang digunakan. Secara makna semantik, judul-judul berita online yang terdapat dalam klasifikasi ini lebih menekankan kepada pemberitaan yang bersifat informasi umum. Secara spesifik, klasifikasi analisa semantik ini memuat berita secara simultan tentang hari dilaksanakannya Pilkada DKI Putaran kedua, tanggal 19 April dengan judul "Live Report: Pilkada DKI Jakarta Putaran Kedua" yang pertama diupload pada pukul 05:59 WIB.

Saat membaca semua berita dalam klasifikasi ini secara berurutan, kita seolah bisa membayangkan semua peristiwa yang terjadi dihari tersebut. Lebih jauh lagi, detiknews tidak hanya menyampaikan berita, tetapi juga memberikan foto-foto berupa hasil foto dilapangan dan bahkan dilengkapi dengan beberapa video dari beberapa tokoh, seperti video singkat yang memuat aktivitas Sandiaga Uno dipagi hari tanggal 19 tersebut. Adanya foto, video, screnshoot kutipan dari para tokoh lainnya di medsos tentang Pilkada menambah kaya pemahaman kita akan sebuah konteks, dan sekaligus salah satu kelebihan berita media baru (baca; internet) yaitu memiliki multimedia yang menambah daya tarik berita daring bagi masyarakat luas. 
Hal menarik klasifikasi ini, memuat berita tentang Presiden Jokowi dan Wapres Jusuf Kalla yang menggunakan hak pilihnya sebagai warga Jakarta di hari tersebut. Kita mengetahui posisi Pak Jowoki pada Pilkada DKI 2017 ini tidak hanya sebagai presiden yang menggunakan hak pilihnya sebagai warga negara, tetapi Presiden Jokowi juga memiliki kerterkaitan emosi yang cukup mendalam dalam Pilkada DKI 2017 ini. Hal tersebut karena kandidat pentahana yang saat itu, Gubernur Ahok adalah mantan Wakil Presiden DKI saat Jokowi masih menjabat Gubernur DKI 2014-2019, sementara Mantan Menteri Pendidikan dan Kebudayaan Anis Baswedan adalah mantan anak buah Presiden Jokowi.

Berita lainnya memuat kegiatan tokoh ulama penggerak Aksi 212, Ustad Habib Rizieq. Adanya beberapa berita khusus tentang Habib Rizieq memberikan pesan tersirat, yaitu beliau diakui sebagai tokoh yang lantang menyuarakan aspirasinya terkait kasus Al-Maidah 511.

Terakhir, adanya 2 berita khusus yang terkait dengan aparat keamanan, Kapolri, Kapolda dan Pangdam Jaya Cek Pencoblosan di TPS dan Polisi-TNI Kenakan Pin 'Aman Ada Kami' di Pilgub DKI, seolah menyampaikan pesan bahwa Pilkada DKI 2017 ini harus berjalan dengan aman dan mereka akan memastikannya.

\section{Klasifikasi Analisis Isi Semantik Penyifatan}

Dalam kelompok klasifikasi semantik penyifatan ini terdapat 17 berita yang ditampilkan. Peneliti memasukkan beritaberita yang menggunakan menggunakan angle personal sebagai judul berita dalam klasifikasi ini. Judul berita dalam klasifikasi analisa isi penyifatan ini terasa lebih personal karena menyorot sisi pribadi setiap para kandidat. Sebagai contoh, Anis Baswedan memberikan pesan pertamanya sebagai Gubernur terpilih DKI Jakarta dengan mengatakan' Kami Mengabdi kepada Seluruh Warga Jakarta". Pesan ini terasa menyejukkan karena menunjukkan Anis Baswedan ingin merekatkan semua elemen masyarakat, sekaligus menyatakan Anis
Baswedan akan melayani semua warga yang ada dibawah kepemimpinannya, meskipun tidak memilihnya. Pernyataan Ahok di sisi lain juga menunjukkan penerimaannya akan hasil yang telah diprediksi dan dinyatakan banyak quick count. Pernyataan Ahok bisa dipahami, menimbang selisih suara $17 \%$ sangat signifikan dan sekaligus menunjukkan seolah semua pendukung Agus Yhudoyono pada putaran pertama melimpahkan seluruh suaranya pada Anis-Sandi saat putaran kedua.

Adapun berita dengan judul "Nyoblos di TPS 01, Sandiaga Pamer Salam 3 Jari" terasa lebih cair dan seolah mengatakan Sandiaga yakin akan terpilih.

Berita lainnya yang menarik dalam klasifikasi ini disebutkannya para tokoh politik yang berada dibelakang setiap kandidat; Prabowo dan Megawati. Secara terbuka, para kandidat diberitakan hari itu terus mengadakan konsolidasi dengan tokoh politik utama yang mendukungnya.

\section{Klasifikasi Analisis Isi Semantik Pernyataan}

Dalam kelompok klasifikasi semantik penunjukan ini terdapat 4 berita yang ditampilkan. Sedikitnya berita dalam klasifikasi ini karena berita yang termasuk dalam katagori ini tidak banyak. Peneliti memprediksi setelah tanggal 19 April, berita dalam klasifikasi ini akan lebih banyak, karena Anis-Sandi akan banyak mengeluarkan pernyataan-pernyataan seiring dengan tanggung jawab yang akan dipundak mereka.

Sangat menarik adanya berita yang mengangkat hadirnya Ketua Umum Golkar , yang akrab dipanggil Ical dalam jumpa pers kemenangan pasangan Anis-Sandi dan direspon dengan cukup tajam oleh politisi Golkar lainnya. Kita tahu dalam pilkada kali ini, Golkar dalam posisi bersebrangan secara afiliasi politik terhadap Anis-Sandi. Namun, kehadiran Abu Rizal Bakrie seolah menunjukkan pesan lain.

Detiknews sebagai institusi menutup serangkaian berita di akhir dengan baik dengan menyatakan terima kasihnya kepada warga DKI Jakarta, karena Pilkada DKI 2017 telah berlangsung dengan aman. Hal ini 
penting untuk dinyatakan sebagai bentuk apresiasi kepada warga Jakarta.

Berita terpenting dalam klasifikasi analisis isi semantik pernyataan ini adalah (1) Pilgub DKI Putaran Kedua; Ahok-Djarot Ucapkan Selamat Atas Kemenangan AniesSandi dan (2) Anies-Sandi Menang Versi Quick Count. Kedua berita ini merupakan informasi terpenting tentang siapa kandidat pemenang PIlkada DKI 2017 dan merupakan berita inti yang sekaligus menutup serangkaian berita hari itu.

\section{SIMPULAN}

Berdasarkan hasil penelitian di atas dapat disimpulkan bahwa semua berita yang masuk dalam klasifikasi analisis isi semantik berita online detiknews tanggal 19 April 2017 tentang Pilkada DKI Jakarta telah mewakili semua peristiwa penting yang terjadi hari itu, tidak hanya memberitakan hal-hal yang sifatnya hardnews (misalnya, pernyataan sikap), tetapi juga berita-berita yang sifatnya soft news, seperti aktivitas pribadi setiap kandidat hari itu. Sementara itu, kecepatan berita online terlebih dalam bentuk live report membuat para pembaca berada dalam satu ruang dan waktu yang sama. Dengan membaca ulang pemberitaan, kita dapat merekonstruksi peristiwa yang terjadi saat itu. Dengan kecepatan internet sekarang, live report menjadi salah satu unggulan pemberitaan online.

Berita-berita online tentang Pilkada DKI 2017 di Detiknews mencerminkan semua karakter yang terdapat dalam berita online: interaktivitas, immediacy, multimedia capability dan non-liniearity.

Keterbatasan penelitian ini antara lain karena sedikitnya jumlah berita yang diteliti dan objek penelitian selama 1 hari, maka belum bisa menggambarkan secara keseluruhan tentang dinamika Pilkada DKI 2017 dalam pemberitaan Detik.news. Namun secara keseluruhan, peneliti menilai konsep analisis isi semantik yang dipakai dengan tujuan untuk menggambarkan isi komunikasi berita online yang terjadi pada tanggal 19 April 2017 telah terpenuhi.

\section{DAFTAR PUSTAKA}

Basri, H. 2014. Using qualitative research in accounting and management studies: not a new agenda. Journal of USChina Public Administration, October 2014, Vol.11, No.10.

Bungin, Burhan. 2012. Penelitian Kualitatif; Komunikasi, Ekonomi, Kebijakan Publik, dan Ilmu Sosial lainnya. Kencana. Jakarta

Bulaeng, Andi. 2004. Metode Penelitian Komunikasi Kontemporer, Penerbit Andi. Yogyakarta

Cresswell, John W, 1994. Research Design: qualitative, quantitative and mixed method approaches, SAGE Publications

Hadari Nawawi, H. Murni Martini, 1966. Penelitian Terapan, Yogyakarta: GajahMada University Press,cet . 2

Hadi, I.P., 2010. Perkembangan teknologi komunikasi dalam era jurnalistik modern. Scriptura, 3(1), pp.69-84.

Hasfi, N., 2009. Tantangan Jurnalis di Era Globalisasi Informasi. In Forum.

Krippendorff, Klaus. 1991. Content Analysis: an introduction ot its Methodology, SAGE Publications.

Kriyantono. 2012. Public Relations \& Crisis Management: Pendekatan Critical Public Relations Etnografi Kritis \& Kualitatif. Jakarta: Kencana

McCusker, K., \& Gunaydin, S. (2015). Research using qualitative, quantitative or mixed methods and choice based on the research. Mukhtar. 2013. Metode Penelitian Deskriftif Kualitatif. Jakarta : GP Press Group

Soehartono, Irawan, 1999. Metode Penelitian Sosial, PT. Remaja Rosda Karya,Bandung

Objektivitas Berita Pada Media dalam Jaringan. (Analisis Isi Berita Pemilihan Gubernur DKI Jakarta pada Detiknews selama Masa Kampanye Periode I) Vience Mutiara RumataPuslitbang APTIKA-IKP, 
Jurnal Komunikasi

ISSN 2580-8338

Kementerian Komunikasi dan Informatika

Metode Penelitian Kualitatif Analisis Teks. Tugas Mata Kuliah Metodologi Penelitian Komunikasi II. Zatul Fadli dkk. Magister Ilmu Komunikasi. Fakultas Ilmu Sosial dan Politik, Universitas Sumatera Utara. 2016

//chyrun.com/peringkat-5-media-onlinepopuler-di-indonesia-besertapendapatanya/

//www.academia.edu/24311918/

//news.okezone.com/read/2017/03/04/338/163 4341/ini-hasil-pilgub-dki-putaranpertama

//megapolitan.kompas.com/read/2017/04/30/0 6030941/ini.hasil.rekapitulasi.suara.pu taran.kedua.pilkada.dki.jakarta 